\title{
Pendidikan Seks Pada Remaja
}

\author{
Stefanus M. Marbun, Kalis Stevanus ${ }^{1)^{*}}$ \\ ${ }^{1}$ Sekolah Tinggi Teologi Tawangmangu \\ ${ }^{*}$ Email : Stefanus.marbun@gmail.com
}

Diterima:31 Okt. 2019 / Direvisi:27 Nov. 2019 / Disetujui:27 Nov. 2019

\begin{abstract}
Abstrak
Pendidikan seks sangatlah penting untuk diberikan kepada para remaja, bahkan sejak masih kanak-kanak. Anak-anak dan remaja rentan terhadap informasi yang salah mengenai seks. Tujuan penulisan ini, diharapkan melalui pendidikan seks, orangtua dapat memberikan informasi yang sepatutnya sesuai kebutuhan dan umur anak. Selain itu, dengan pendidikan seks anak juga dapat diberitahu mengenai berbagai perilaku seksual berisiko sehingga mereka dapat menghindarinya. Dengan menggunakan pendekatan penelitian kualitatif yaitu studi literature, dengan menggali berbagai informasi berkenaan dengan pendidikan seks pada remaja, maka diperoleh hasil, pertama: pendidikan seks harus dianggap sebagai bagian dari proses pendidikan untuk memperkuat pengembangan kepribadian. Kedua, orangtua memiliki peran penting untuk menanggulanggi perilaku seks yang menyimpang adalah dengan cara orangtua mengajarkan pendidikan seks secara langsung dan kontinyu pada anak sedini mungkin di dalam keluarga sesuai Alkitab dan norma-norma masyarakat setempat agar remaja meneima seksualitasnya yang adalah bagian integral kehidupannnya dengan penuh tanggung jawab.

Kata-kata Kunci: Pendidikan Seks; Remaja; Kristen
\end{abstract}

\section{Abstract}

Sex education is very important to be given to adolescents, even from childhood. Children and adolescents are vulnerable to misinformation about sex. The purpose of this writing, is expected through sex education, parents can provide information that is appropriate for the needs and age of the child. In addition, with child sex education can also be informed of various risky sexual behavior so they can avoid it. Using a qualitative research approach, namely 
the study of literature, by exploring various information regarding sex education in adolescents, the results are obtained, first: sex education must be considered as part of the education process to strengthen personality development. Second, parents have an important role to deal with deviant sexual behavior is that parents teach sex education directly and continuously to children as early as possible in the family according to the Bible and local community norms so that teenagers accept their sexuality which is an integral part of their lives with full responsibility answer.

Key Words: Sex Education; Teenagers; Christian

\section{Pendahuluan}

Generasi muda merupakan generasi penerus keluarga, gereja maupun bangsa. Generasi muda perlu dibina dan dibimbing dengan memberikan pendidikan, baik berupa pendidikan sekuler maupun pendidikan rohani. Pendidikan adalah salah satu hal penting dalam kehidupan setiap manusia. Gagalnya pendidikan merupakan kegagalan kehidupan masa depan sebuah bangsa maupun gereja. Perintah Tuhan untuk mendidik anak seperti tertulis dalam Efesus 6:4 dikatakan,"...tetapi didiklah mereka di dalam ajaran dan nasihat Tuhan". Orangtua telah mendapat mandat dari Tuhan untuk mendidik anak-anak mereka kepada ajaran dan nasihat Tuhan. ${ }^{1}$

Di zaman sekarang para orang tua sudah semakin sadar bahwa pentingya untuk memberikan pendidikan yang baik bagi anak-anak mereka. Namun pendidikan seks seakan luput dari perhatian, baik oleh orang tua, sekolah, apalagi gereja. Tidak adanya perhatian terhadap pendidikan seks bagi remaja memungkinkan adanya anggapan bahwa membicarakan seks adalah hal yang tabu bahkan yang paling ekstrim adalah berpendapat bahwa hal tersebut mendorong anak remaja untuk melakukan hubungan seks. Sebagian besar masyarakat masih memiliki paradigma pendidikan seks adalah sesuatu yang vulgar dan sepatutnya remaja harus belajar dari lingkungannya. Pandangan masyarakat pada umumnya ini ditegaskan oleh Abineno, bahwa rata-rata orang tua membicarakan seks dan seksualitas adalah sesuatu pemahaman yang baru. Hampir semua orang tua di Indonesia tidak pernah mendapatkan pendidikan seksual. Bahkan mereka juga tidak pernah membaca sesuatu yang berindikasi mengenai pendidikan seksual. Mereka "buta huruf" di bidang seks dan

\footnotetext{
${ }^{1}$ Kalis Stevanus, Menjadi Orangtua Bijak Solusi Mendidik Dan Melindungi Anak Dari Pengaruh Pergaulan Buruk (Yogyakarta: Yayasan Pustaka Nusatama, 2016), 41
} 
seksualitas. Tugas ini tidak bisa diwakilkan kepada orang lain kecuali orang tua harus mengambil tanggung jawab untuk berperan mengajarkan pendidikan seks terhadap anak-anaknya. ${ }^{2}$

Masa remaja adalah masa yang paling signifikan untuk mendapatkan pendidikan seks. Sedini mungkin orang tua harus prepentif untuk mengantisipasi hal-hal yang tidak diinginkan terjadi pada diri anak tersebut. Masa remaja adalah masa peralihan dari masa anak-anak menuju dewasa yakni dari umur 12 tahun sampai 18 tahun, yang ditandai dengan kematangan fisik, intelektual. Dengan masa ini para remaja siap menerima dan mencerna apa yang diajarkan kepada mereka. Remaja mulai terlihat mengalami perubahan-perubahan jasmaniah berkaitan dengan proses kematangan jenis kelamin (gender) secara biologis. Pada masa ini juga terlihat perkembangan kepribadian, intelektual, psikosekssialitas, emosinalitas yang mempengaruhi tingkah laku para remaja, dan psikososial yang berhubungan dengan berfungsinya seseorang dalam lingkungan sosial, yakni dengan melepaskan diri dari ketergantungan pada orang tua, pembentukan rencana hidup dan pembentukan sistem nilai-nilai. ${ }^{3}$ Oleh sebab itu masa remaja adalah masa yang sangat rentan terhadap masuknya nilai-nilai pengajaran yang destruktif. Nilai-nilai yang destruktif dapat masuk melalui pergaulan. Alkitab sudah memperingatkan bahwa pergaulan buruk merusakkan kebiasaan baik yang dibangun sekian tahun lamannya (1 Kor 15:33). Segalanya yang telah diberikan orangtua kepada anak baik ajaran, pendidikan, biaya dan sebagainya, semuanya bisa menjadi rusak oleh pengaruh pergaulan buruk. Pergaulan buruk bukan hanya dengan sesama, tetapi juga bisa terjadi lewat bacaan, tontonan, musik, dan lain sebagainya. Biarlah kegentingan dunia hari ini menyadarkan para orangtua untuk lebih bersungguh-sungguh mendidik dan melindungi remaja. ${ }^{4}$

Bila pendidikan seks tidak diberikan sedini mungkin pada anaka-anak remaja, maka kemungkinan besar akan banyak menjadi korban seperti apa yang diungkapkan oleh Santrock, bahwa ada anak remaja bernama Angela berusia 15 tahun dan hamil diluar nikah. Ia mengatakan, "Aku hamil 3 bulan, dan kehamilan ini akan merusak seluruh hidupku. Aku telah menyusun semua rencana bagi masa depan dan sekarang rencana-rencana itu hancur berantakan.

2 J.L. Ch. Abineno, Seksualitas dan Pendidikan Seksualitas Seksual, (Jakarta: Bpk. Gunung Mulia, 2002), 30.

${ }^{3}$ Singgih D. Gunarsa dan Yulia, Psikologi Perkembangan Anak dan Remaja, (Jakarta: BPK Gunung Mulia, 2006), 201-202.

${ }^{4}$ Kalis Stevanus, Mendidik Anak (Yogyakarta: Lumela, 2018), 1-2 
Aku tidak memiliki seseorang untuk tempat aku menceritkan semua masalahku. Aku tidak dapat bercerita kepada orang tuaku. Tidak mungkin mereka dapat memahaminya". Hal ini menjadi dilema dalam keluarga maupun pada masyarakat pada umumnya. ${ }^{5}$ Peristiwa seperti ini sering terjadi dan paling menyedihkan adalah bunuh diri atau dibunuh oleh orang yang menghamili anak remaja tersebut.

Bila pendidikan seks tidak diajarkan sedini mungkin pada anak-anak, maka besar kemungkinan akan terjadi pergaulan bebas, seks bebas, pemerkosaan, sodomi, hamil diluar nikah, aborsi, hidup bersama diluar nikah, dan pelanggaran-pelangaran nilai-nilai moral lainnya. Menyikapi pelanggaran norma-norma susila pada kalangan remaja tersebut, tidak dapat sepenuhnya itu menjadi tanggung jawab remaja tersebut. Mengingat peran orang tualah sesungguhnya meminimalkan pelanggaran tersebut. Di sisi lain ada sebuah dilema bagi orang tua khususnya yang masih terikat dengan budaya Timur karena membicarakan masalah seksualitas adalah sesuatu yang tabu dan tertutup. Oleh sebab itu, sudah saatnya orangtua menyadari perannya untuk memberikan pendidikan seks bagi anak-anaknya.

Bertolak dari masalah-masalah yang dihadapi remaja Kristen saat ini, maka penulis perlu mengkaji lebih jauh mengenai pendidikan seks dalam perspektif Kristen. Diharapkan melalui pemberian pendidikan seks sejak dini, dapat mencegah perilaku seks bebas ketika anak menginjak remaja atau pubertas.

\section{Metode Penelitian}

Penulis menggunakan jenis penelitian kualitatif dengan pendekatan studi pustaka (library research) yang memaparkan prinsip Kristen tentang pendidikan seks bagi remaja. Studi pustaka (library research) adalah kegiatan untuk menghimpun informasi yang relevan dengan topik atau masalah yang menjadi obyek penelitian. ${ }^{6}$ Sumber literatur yang digunakan dalam penelitian ini adalah sumber yang telah terpublikasi seperti karya dari Abineno, Anne K. Hershberger dan Michael A. Carrera, Benson dan Mark H. Senter III, Warren S, Brenna B. Jones, Stanton L, Herlianto, Singgih D. Gunarsa sebagai landasan teoretis dalam

\footnotetext{
${ }^{5}$ John W. Santrock, Life-Span Development Vol 2, terjemahan: Achmad Chusairi \& Juda Damanik, (Jakarta: Erlangga, 2002), 25-26.

${ }^{6} \mathrm{https}: / /$ www.transiskom.com/2016/03/pengertian-studi-

kepustakaan.html\#: :targetText=Studi\%20kepustakaan\%20adalah\%20kegiatan\%20untuk,\%2C \%20dan\%20sumber\%2Dsumber\%20lain. Diakses 20 November 2019.
} 
penelitian ini. Berbagai informasi yang diperoleh dari beberapa literatur tersebut kemudian disintesakan yang akhirnya menjadi simpulan. Simpulan tersebut kemudian disusun secara logis dan sistematis deskriptis untuk menjawab pokok permasalahan dalam penelitian ini.

\section{Pembahasan}

\section{Perkembangan Remaja}

Di dalam memberikan pendidikan seks bagi remaja, sebagai upaya mencegah atau menghindari perilaku seks bebas di kalangan remaja, adalah sangat penting bagi seorang pendidik, orang tua, maupun si remaja itu sendiri untuk mengetahui perkembangan remaja. Dengan demikian, para pendidik dan orang tua mampu mengatasi persoalan-persoalan anak-anak remaja tersebut.

\section{Perkembangan fisik remaja}

Pada masa remaja terjadi pertumbuhan dan perkembangan fisik yang sangat pesat. Perubahan utama adalah perubahan ukuran tubuh, baik tinggi maupun berat badan. Diantara anak-anak wanita, rata-rata peningkatan tinggi badan selama dua tahun sebelum haid adalah 5,5 inci. Setelah haid, tingkat pertumbuhan menurun sampai kira-kira 1 inci setahun dan berhenti sekitar delapan belas tahun. ${ }^{7}$ Bagi anak laki-laki, pertumbuhan tinggi badan dimulai rata-rata pada usia 12,8 tahun dan berakhir rata-rata pada umur 15,3 tahun, dan puncaknya mencapai empat belas tahun. ${ }^{8}$ Peningkatan tinggi badan terjadi setahun sesudah dimulainya masa puber. Sesudahnya, pertumbuhan menurun dan berlangsung lambat sampai usia dua puluh atau dua puluh satu.

\section{Perkembangan psikologi remaja}

Perkembangan dan pertumbuhan psikologi adalah perkembangan ciri-ciri psikologi tertentu pada diri seseorang. Gunarsa menyatakan bahwa sesungguhnya perkembangan psikologi sebenarnya banyak dipengaruhi oleh faktor-faktor fisiologis. ${ }^{9}$ Faktor-faktor fisiologis ini ditentukan oleh genetika, di samping proses pematangan yang mengarahkan pertumbuhan dan perkembangan. Masa remaja juga merupakan masa penuh gejolak emosi dan ketidakseimbangan. Dengan demikian remaja sangat mudah terpengaruh oleh lingkungan sosial. Remaja diombang-ambingkan oleh munculnya kekecewaan

\footnotetext{
${ }^{7}$ Elizabeth B. Hurlock, 188

${ }^{8}$ Ibid

${ }^{9}$ Singgih D. Gunarsa \& Yulia, 205
} 
dan penderitaan, meningkatnya konflik, pertentangan-pertentangan dan krisis penyesuaian, impian dan khayalan, pacaran dan percintaan, keterasingan dari kehidupan dewasa dan norma kebudayaan. ${ }^{10}$

Pada remaja awal, mereka belum bisa membedakan antara kenyataan dan imajinasi, karena imajinasi yang masih dibawa dari masa kanak-kanak. Dalam masa ini, remaja awal lebih bersikap kristis, abstrak, bebas, dan kurangnya pengalaman hidup. Mereka memiliki rasa ingin tahu karena berkembanganya pemikiran-pemikiran yang baru. Disamping itu, anak remaja awal sering raguragu untuk mengekspresikan diri sendiri, takut mengalami kegagalan karena kurangnya pengetahuan yang memadai. ${ }^{11}$ Pengertian konsep diri sangat penting bagi remaja awal, khususnya pada tindakan mereka terhadap lingkungan sosialnya. Emosi remaja awal lebih cepat meledak karena kurang stabilnya emosi, bahkan cenderung menarik diri dari masyarakat, kehilangan semangat, perasaan bersalah, dan prustasi bila sesuatu hal mengancam dirinya.

Memasuki tahap remaja akhir, mereka berorientasi pada pertanyaan "mengapa", "apa" dan "bagaimana", karena pemikiran mereka sedang menuju dewasa. ${ }^{12}$ Kekuatan pemikiran remaja akhir yang sedang berkembang membuka cakrawala kognitif dan cakrawala sosial yang baru. ${ }^{13}$ Pemikiran mereka semakin abstrak, logis dan idealis, lebih mampu menguji pemikiran diri sendiri, pemikiran orang lain, dan apa yang orang lain pikirkan tentang diri mereka, serta cenderung menginterpretasikan dan memantau dunia sosial. Pengalaman remaja akhir sudah lebih luas, bahkan mereka tertarik untuk mengembangkan lapangan pekerjaan yang beragam. Mereka memiliki pemikiran yang tajam dalam berpikir abstrak, mereka menyukai debat, diskusi, berpikir bebas dan menentang ide-ide atau konsep-konsep yang sebelumnya telah disetujui. Remaja akhir juga lebih cenderung egosentris dan sering berpikir lebih tinggi dari pada kenyataannya. Rasa takut, marah dan kasih biasanya diperlihatkan secara emosional. Emosi yang tinggi ini sangat membutuhkan penerimaan dan pengawasan orang tua mereka. ${ }^{14}$

\footnotetext{
${ }^{10} \mathrm{Ibid}$

${ }^{11}$ Paulus Lilik Kristianto, Prinsip \& Paraktik Pendidikan Agama Kristen, (Yokyakarta: ANDI, 2006), 98

${ }^{12} \mathrm{Ibid}$

${ }^{13}$ John W. Santrock, Life-Span Development Vol 2, (Jakarta: Erlangga, 2002), 10

${ }^{14}$ Dadang Suleman, Psikologi Remaja (Bandung : Mandar Maju,1995), 41-42
} 


\section{Perkembangan sosial remaja}

Seiring dengan perkembangan fisik remaja, yang tersulit bagi mereka adalah yang berhubungan dengan penyesuaian sosial. ${ }^{15}$ Jika pada masa sebelumnya, mereka hanya membutuhkan teman bermain, namun pada usia ini mereka mulai mencari persahabatan yang lebih berarti. Biasanya mereka akan melakukan apa saja untuk menciptakan persahabatan serta mempertahankan persahabatan. ${ }^{16}$ Remaja harus menyesuaikan diri dengan lawan jenis dalam hubungan sebelumnya yang belum pernah ada dan harus menyesuaikan orang dewasa di luar lingkungan kelurga dan sekolah. Lingkungan kebudayaan sangat berperan dalam perkembangan sosial remaja. Karena lingkungan sosial memegang peranan besar dalam perkembangan kepribadiannya, maka dapat dikatakan bahwa remaja belajar dari dan dalam lingkungan dengan kebudayaannya. Perkembangan sosial merupakan suatu proses belajar sosial yang berkesinambungan. Sebagai hasil belajar dan dari pengalaman lingkungan, maka muncullah perilaku yang baru pada diri anak remaja.

\section{Perkembangan seks remaja}

Pada tahap pubertas, perkembangan seks remaja ditandai dengan perkembangan ciri seks primer yaitu pada organ-organ rerproduksi dan ciri seks sekunder yang memiliki pengaruh langsung pada dorongan seksual intrinstik (hakiki/dasar), walaupun tentu saja terdapat perbedaan yang dramatis di antara kedua jenis kelamin.

Dalam ciri seks primer pada remaja laki-laki, gonad ${ }^{17}$ atau teste ${ }^{18}$ yang terletak di dalam scrotum ${ }^{19}$ di luar tubuh dan pada usia 14 tahun baru sekitar $10 \%$ ukurannya matang. Kemudian terjadi pertumbuhan pesat selama satu atau

${ }^{15}$ Elizabeth B. Hurlok, 213

${ }^{16}$ Anni Dyck, Tantangan dan Kebutuhan Remaja (Malang : YPPII, 1982 ), 23

${ }^{17}$ Gonad= a reproduktif gland (as an ovary or testis) that produces gametes. MerriamWebster's Collegiate Dictionary (11th Edition) (U.S.A,: Merriam-Webster Incorporated, 2003), 538. Dalam bahasa Indonesia disebut "kelengar kelamin". Kamus Besar Bahasa Indonesia,..., 368

${ }^{18}$ Testes $=$ testis $=$ a typically paired male reproductive gland that produces sperm and secretes testosterone and that in most mammals is contained within the scrotum at sexual maturity. Merriam-Webster's Collegiate Dictionary,...1291. dalam bahasa Indonesia disebut "alat kelamin laki-laki yang menghasilkan mani; buah zakar". Kamus Besar Bahasa Indonesia,..., 1187.

${ }^{19}$ Scrotum = the external pouch that in most mammals contains the testes. MerriamWebster's Collegiate Dictionary,..., 1291. Dalam bahasa Indonesia disebut "kantung buah pelir, kantung kemaluan". John M. Echols \& Hassan Shadily, Kamus Inggris Indonesia, (Jakarta: Gramedia, 2003), 506. 
dua tahun, setelah itu pertumbuhan menurun. Testis akan berkembang penuh pada usia 20 atau 21 tahun. Seiring dengan pertumbuhan testis, penis juga mengalami pertumbuhan panjang dan besarnya. Bila fungsi organ-organ reproduksi laki-laki sudah matang, maka biasanya mulai terjadi ejakulasi yang langsung terkait dengan pengalaman seksual yang menyenangkan. Maka privasi yang disertai kapasitas tersebut terletak pada prilaku masturbasi. ${ }^{20}$

Pada anak remaja wanita, organ-organ reproduksi tumbuh dalam kecepatan yang berbeda selama masa puber. Berat uterus ${ }^{21}$ anak usia 11 atau 12 tahun berkisar 5,3 gram. Pada usia 16 tahun rata-rata beratnya 43 gram. Tuba falopi sel telur, dan vagina juga tumbuh pesat pada saat ini. ${ }^{22}$ Petunjuk pertama bahwa mekanisme reproduksi wanita menjadi matang adalah datangnya haid, dan akan terjadi kira-kira secara berkala setiap dua puluh delapan hari sampai mencapai menopause, pada akhir empat puluhan atau awal lima puluh tahun.

Organ seks remaja lak-laki dan wanita mengalami ukuran yang matang pada akhir masa remaja. Kematangan seksual ditandai dengan pengeluaran sperma pada waktu-waktu tertentu untuk laki-laki, akibat testis yang sudah matang. Sedangkan untuk remaja putri dengan datangnya menstruasi atau haid (pengeluaran sel telur yang tidak dibuahi bersama lendir dan darah) dan biasanya disertai rasa sakit, kejang-kejang, gemetar pada lutut dan kaki. Itu adalah akibat adaptasi dan metabolisme tubuh. Sebagai akibat dari gejala tersebut remaja putri sering kelihatan lesu dan cepat tersinggung. ${ }^{23}$

\section{Perkembangan moral dan spiritual remaja}

Perbedaan secara alamiah dari remaja awal dan remaja akhir akan mempengaruhi kondisi rohani dan pengetahuannya. ${ }^{24}$ Remaja awal perlu mempertajam perasaan untuk membedakan yang benar dan salah. Mereka mempunyai hasrat untuk diterima, mereka menjadi sensitif dengan suara hati. Problem remaja awal adalah perilaku yang tidak terpuji, dan dorongan hati yang

${ }^{20}$ Sawitri Supardi Sadarjoen, Bunga Rampai Kasus Gangguan Psikoseksual, (Bandung: Refika Aditama, 2005), 9.

${ }^{21}$ Uterus = a muscular organ of the female mammal for containing and usu, for npurishing the young during development prior to birth - called also womb. Merriam-Webster's Collegiate Dictionary, ..., 1379. Dalam bahasa Indonesia disebut "Anak rahim, peranakan",

Kamus Besar Bahasa Indonesia, ..., 1257.

${ }^{22}$ Elizabeth B. Hurlock, 189

${ }^{23}$ Indung Abdullah Saleh, 139-140

${ }^{24}$ Paulus Lilik Kristianto, Prinsip \& Praktik Pendidikan Agama Kristen, ...100 
egois. ${ }^{25}$ Mereka memiliki hasrat untuk belajar, termasuk belajar untuk bertanggung jawab.

Konsep Allah bagi remaja awal dipahami sebagai manusia biasa, tetapi memiliki kemampuan supernatural. Mereka memiliki kerangka pemikiran bahwa manusia tidak sepenuhnya jahat atau baik, tetapi ada diantara keduaduanya. Allah dipahami mengendalikan dan menggunakan alam untuk ikut campur dalam masalah manusia, tetapi tidak secara langsung. Pada tahap usia ini, Allah dipandang lebih bersifat pribadi. Anak laki-laki cenderung menggambarkan Tuhan sebagai pribadi yang spontan, sedangkan anak wanita memahami Allah sebagai pribadi yang statis. Pada usia remaja ini, mereka memahami iman Kristen itu sebagai konsep yang abstrak. ${ }^{26}$

Tahap remaja akhir, mereka memperhatikan pertanyaan dan mulai menyangsikan perkara rohani serta ingin bertanya mengapa dan bagaimana. Mereka sangat idealis dan menuntut bukti dan bersungguh-sungguh dalam mempelajari tentang agama. Keinginan mereka untuk belajar tentang hal-hal rohani menunjukkan pentingnya spiritual bagi mereka. Remaja akahir umumnya akan menanyakan tiga pokok pertanyaan: "Siapa saya?", "Bagaimana saya bekerja dengan baik?”, “Apakah itu bermanfaat?”. Mereka menginginkan dan memerlukan tantangan rohani. Sebagaimana dikemukakan Mulyono, bahwa perkembangan kehidupan rohani remaja tidak dapat dilepaskan dari perkembangan intelektualnya. Perkembangan intelektual itu menurut, pada satu sisi, remaja bersikap kritis dengan menilai segala sesuatu berdasarkan akal dan bukti-bukti yang bisa dilihat. Tetapi di satu sisi lain, sebenarnya remaja juga haus untuk memiliki pengalaman religius. ${ }^{27}$

Remaja akhir memahami Allah sebagai penegak hukum-hukum alam. ${ }^{28}$ Allah dipandang memiliki perhatian terhadap manusia dan tidak sekedar menghakimi mereka. Remaja akhir ini juga menyadari bahwa Allah bersifat lebih dari sekedar pengalaman sensorik (perjumpaan seseorang dengan Allah bersifat internal dan mental, bukan secara eksternal). Remaja akhir kadang kala memiliki perasaan tidak layak di hadapan Allah karena mereka memiliki sebuah konsep tentang ketiadaan Allah secara nyata. Disamping itu remaja akhir juga memiliki minat pada hal-hal yang ideal dan ideologi pada saat mereka mencari

${ }^{25}$ Paul D. Mieyer, M.d, Frank B. Minirth, dkk, Pengantar Psikologi dan Konseling

Kristen, Volume 2, (Yokyakarta: ANDI, 2004), 107.

${ }^{26} \mathrm{Ibid}, 102$.

${ }^{27}$ Y. Bambang Mulyono, Mengatasi Kenakalan Remaja (Yogyakarta : Andi, 1996), 24

${ }^{28}$ Paul D. Mieyer, M.d, Frank B. Minirth, dkk, 103. 
indentitas diri. Mereka siap melakukan komitmen rohani yang serius, meskipun kekristenan merupakan hal yang membosankan bagi mereka sebelumnya. Mereka memiliki kebutuhan yang kuat untuk memperkuat hati nurani dan mencari arti hidup. ${ }^{29}$

\section{Pendidikan Seks Remaja}

Pandangan Iman Kristen Tentang Seks dan Seksualitas

Tuhan menciptakan perbedaan organ seks untuk membedakan gender antara pria dan wanita. Apa yang dijadikan Tuhan "sungguh amat baik" (Kej. 1:31). Salah satu tujuan Tuhan menciptakan seks dan seksualitas dalam pernikahan adalah untuk reproduksi (Kej. 1:28). Pernikahan adalah sesuatu yang baik, berlawanan dengan kesendirian (Kej. 2:18). ${ }^{30}$ Juga dikatakan Stevanus, bahwa seks bebas adalah dosa dan hal itu selalu menjadi masalah dan membawa masalah hingga ke jenjang pernikahan. Tuhan merancang ekspresi seksual untuk menjadi eksklusif, intim, permanen, menggembirakan dan mengikat. Dan Tuhan telah menetapkan pernikahan menjadi satu-satunya wadah bagi ekspresi seksual tersebut (Kej 2:24-25). ${ }^{31}$ Dengan kata lain, seks dan seksualitas pada dasarnya baik dan harus dihormati, bukan untuk ditabukan atau sebaliknya dieksploitasi.

\section{Pengertian Pendidikan Seks}

Pendidikan seksual menurut Sarwono yang dikutip Reny Safita adalah suatu informasi mengenai persoalan seksualitas manusia yang jelas dan benar meliputi proses terjadinya pembuahan, kehamilan sampai kelahiran, tingkah laku seksual yang diberikan sepatutunya berkaitan dengan norma-norma yang berlaku di masyarakat. ${ }^{32}$ Pendidikan Seks adalah suatu pengetahuan mengenai segala sesuatu yang berhubungan dengan jenis kelamin. Ini mencakup mulai dari pertumbuhan jenis kelamin, bagaimana fungsi kelamin sebagai alat reproduksi, bagaimana perkembangan alat kelamin itu pada wanita dan pada laki-laki, menstruasi, mimpi basah, dan sebagainya, sampai kepada timbulnya birahi karena adanya perubahan pada hormon-hormon. Termasuk nantinya masalah perkawinan, kehamilan dan sebagainya. ${ }^{33}$

${ }^{29}$ Lilis Emindyawati, "Peranan Guru Pendidikan Agama Kristen Terhadap Perilaku Siswa-Siswi”, Fidei: Jurnal Teologi Sistematika dan Praktika, Vol. 2, No. 1, Juni 2019, 47-48.

${ }^{30}$ Kalis Stevanus, Cekcok tapi Sudah Cocok (Yogyakarta: Andi, 2015), 4

${ }^{31}$ Kalis Stevanus, Bible, Pray and Love (Yogyakarta: Andi, 2015), 16

${ }^{32}$ Reny Safita,"Peranan Orang Tua Dalam Memberikan Pendidikan Seksual Pada Anak ", Jurnal Edu-Bio, Vol. 4, Tahun 2013: 34

${ }^{33}$ Ibid,. 35 
Gunarso sebagaimana dikutip Safita, menyatakan bahwa tujuan dari pendidikan seksual adalah untuk membuat suatu sikap emosional yang sehat terhadap masalah seksual dan membimbing anak ke arah hidup dewasa yang sehat dan bertanggung jawab terhadap kehidupan seksualnya. ${ }^{34}$ Benar apa yang dikemukakan Stanton dan Brenna bahwa pendidikan seksual adalah merupakan pembentukan karakter. ${ }^{35}$ Pendidikan mengenai seksualitas bukan semata-mata memberikan informasi yang akurat dan tepat pada waktunya. Namun juga harus membentuk nilai-nilai dan sikap anak-anak, membentuk pandangan mereka tentang dunia, mempraktekkan apa yang diajarkan (menjadi teladan), memberikan kepada anak-anak kekuatan emosi yang akan mereka butuhkan untuk membuat keputusan yang saleh, dan menanamkan dalam diri mereka ketrampilan untuk melaksanakan keputusan-keputusan yang baik yang telah mereka buat. Penting dipahami bahwa perilaku anak-anak akan timbul dari hati mereka, dan akan dibentuk oleh hubungan dan pengabdian mereka kepada Allah. Dengan demikian prioritas utama di dalam pendidikan seks haruslah mempengaruhi pertumbuhan rohani mereka.

\section{Urgensi Pendidikan Seks}

Pendidikan seks remaja merupakan tanggung jawab orang tua. Dalam upaya menghindari perilaku seks bebas yang beresiko, peran orang tua dalam masa tumbuh kembang remaja sangatlah penting. Disamping itu, para orang tua dalam menyikapi perubahan zaman ini secara khusus zaman era informasi ini, orang tua harus menempatkan diri menjadi sahabat bagi para anak remaja. Hubungan orang tua dengan remaja terjalin dengan baik dan dapat menyelesaikan masalah remaja dengan baik dan tuntas, diperlukan komunikasi yang baik dan efektif.

Masyarakat masa kini telah berubah dan kiprah kehidupan manusia semakin cepat di era teknologi ini. Waktu berkumpul keluarga semakin singkat bahkan tidak ada lagi. Keluarga telah terbagi-bagi oleh aktifitas, pekerjaan, tekanan-tekanan, dan dipikat oleh media hiburan yang menyita banyak waktu. ${ }^{36}$ Komunikasi orang tua dan anak remaja semakin berkurang bahkan mengalami kebuntuan dalam hal komunikasi. Banyak para remaja mencari sumber

\footnotetext{
${ }^{34}$ Ibid

${ }^{35}$ Brenna B. Jones, Stanton L, How And to Tell Your Kids About Seks (Surabaya: Momentum, 2004), 6

${ }^{36}$ Ron Lee Davis, Mentoring, The Strategy Of The Master, (Nashville, Thomas Nelson Publishers, 1991), 186
} 
informasi diluar orang tua yang mengakibatkan hubungan orang tua dan anak remaja renggang. Kemajuan teknologi informasi yang pesat banyak memberikan sumbangsih terjadinya gap antara orang tua dan anak remaja. Orang tua beranggapan dengan adanya telepon genggam (HP), mereka dapat mengawasi anak remajanya.

Demikian juga kemajuan dalam dunia maya, remaja dengan bebasnya keluar masuk kedalam situs-situs yang seharusnya bukan untuk komsumsi orang percaya. Situs-situs porno saat ini tidak hanya menampilkan gambargambar, juga tersedianya video porno yang disediakan secara bebas dan gratis kepada siapa saja. Tempat-tempat inilah yang menjadi sarana pendidikan dan pengetahuan tentang seks remaja. ${ }^{37}$

Menurut suatu penelitian di Amerika Serikat dan Inggris, seperti yang dikutip oleh Sarwono, bahwa sistem pendidikan yang berlaku di suatu daerah tertentu dapat mempengaruhi aktivitas remaja secara umum di daerah itu. ${ }^{38}$ Demikian juga penelitian yang dilakukan oleh Zelnik \& Kim, menyatakan bahwa remaja yang telah mendapat pendidikan seks tidak cenderung lebih sering melakukan hubungan seks, tetapi mereka yang belum pernah mendapat pendidikan seks, cenderung lebih banyak mengalami kehamilan yang tidak dikehendaki. ${ }^{39}$

Melihat situasi dan kondisi sosial masyarakat saat ini yang diperhadapkan dengan krisis moral secara khusus kalangan kaum muda remaja, maka seharusnya menyadarkan orang tua untuk memberikan suatu pendidikan seks pada perspektif yang tepat sesuai dengan ajaran Alkitab kepada anak-anaknya sejak dini. Pendidikan seks sudah seharusnya diberikan kepada anak-anak yang sudah beranjak dewasa atau remaja, baik melalui pendidikan formal maupun informal. Ini penting untuk mencegah perilaku seks yang salah, misalnya seks pranikah, seks bebas, dan sebagainya.

Oleh sebab itu, pendidikan seks merupakan hal yang sangat urgen dan perlu sekali untuk mencegah (preventif), perilaku seks bebas dan mampu menghindari dampak-dampak negatif lainnya. Penulis yakin, bilamana para remaja Kristen telah diperlengkapi dengan pendidikan seks dengan benar dan tepat (berdasarkan iman Kristen), maka prilaku seks bebas dapat dicegah, atau dihindari.

${ }^{37}$ Kalis Stevanus, "Tujuh Kebajikan Utama Untuk Membangun Karakter Kristiani Anak“, BIA: Jurnal Teologi dan Pendidikan Kristen Kontekstual, Volume 1, No.1, 2018: 81

${ }^{38}$ Sarlito Wirawan Sarwono, Psikologi Remaja,.... 133

${ }^{39}$ Ibid, 191. 


\section{Materi Pendidikan Seks Remaja}

Seks merupakan pembicaraan yang menarik di kalangan remaja, baik remaja laki-laki maupun wanita. ${ }^{40}$ Meskipun kadang-kadang mereka malu-malu mengungkapkannya secar terbuka, namun pergumulan tersebut tetap tidak bisa disembunyikan sepenuhnya. Hal ini dapat dipahami karena mereka sedang mengalami gejolak yang dasyat. Artinya, mereka sedang berada di dalam proses pertumbuhan dan perkembangan sehingga mereka merasakan sendiri dampaknya. Kesalahan sekecil apapun dalam pengelolaan dorongan seks masa muda, akan berdampak secara fatal dan menghancurkan diri sendiri.

Para remaja tentu sangat membutuhkan informasi dan pengajaran yang benar tentang seks dan seksualitas. Pengajaran yang salah pasti akan mengakibatkan pemahaman mereka tentang seks dan seksualitas yang keliru. Akibatnya, tidak sedikit para remaja memahami dorongan seksual mereka secara negatif. Oleh karena itu, penyusunan suatu materi pendidikan seks yang akan diberikan kepada remaja sangat signifikan.

Materi pendidikan seks remaja sebaiknya diberikan secara kontekstual, yaitu dalam kaitannya dengan norma-norma yang berlaku dalam kekristenan dan yang berlaku dalam masyarakat: apa yang terlarang, apa yang lazim dan bagaiman cara melakukannya tanpa melanggar aturan. Pendidikan seks yang kontekstual ini jadinya mempunyai ruang lingkup yang luas. Tidak terbatas pada prilaku hubungan seks semata tetapi menyangkut pula hal-hal lain, seperti peran laki-laki dan wanita dalam masyarakat, hubungan laki-laki dengan wanita dalam pergaulan, peran ayah dan ibu serta anak-anak dalam keluarga, dan sebagainya.

Seksualitas kaum remaja bukanlah suatu aktivitas, peristiwa atau perilaku. ${ }^{41}$ Sebaliknya, seksualitas remaja adalah bidang kehidupan yang luas, rumit, dan berpotensi memberi kegembiraan. Seksualitas remaja bersifat spiritual, intelektual, emosional, religius, kultural, dan juga biologis. Berkaitan dengan hal ini dan dari hasil studi psikologi sosial Kristen, berikut ini penulis memaparkan suatu kerangka materi pendidikan seks remaja yang dibagi dalam beberapa bagian yaitu dimensi biologis, dimensi psikologis, dimensi sosial, dan dimensi spiritual.

${ }^{40}$ EB Surbakti, Kenakalan Orang Tua Penyebab Kenakalan Remaja, (Jakarta: Elex Media Komputindo, 2008, 41.

${ }^{41}$ Michael A. Carrera \& Anne K. Hershberger, Seksualitas Pemberian Allah, (Jakarta: BPK Gunung M ulia, 2008), 55. 


\section{Dimensi Biologis}

Remaja ada didalam perkembangan dan perubahan fisik. Maka, para remaja perlu mengerti, memahami dan mengenal tubuhnya secara kongkrit. Dalam dimensi ini, remaja perlu dibimbing bagaiman merasakan dan memahami diri sendiri, dan bagaimana mereka memahami orang lain. Rasa yakin dan aman tentang "kebaikan" tubuhnya dapat memperlancar pengungkapan seksualitas yang sehat. Sebaliknya, keraguan dan kecemasan tentang tubuhnya dapat menghambat pengungkapan seksual.

Misalnya, remaja laki-laki mendapat kesan kuat, bahwa mereka harus berbuat tanpa menggunakan perasaan. Maskulinitas mereka terletak pada tubuh yang tegap dan kemampuan berbuat. Sedangkan remaja wanita belajar supaya disukai kaum laki-laki. Semua perubahan biologis selama pubertas dipantau dan ditafsirkan melalui filter yang ideal menurut budayanya. Remaja wanita dengan cepat memandang tubuhnya secara kosmetik dan berdasarkan penampilan luarnya. Mereka terlanjur menggunakan standar ini dan mengharapkan orang lain mengabsahkan feminitas mereka.

Dalam dimensi bilogis ini, hal-hal yang penting untuk disampaikan kepada para remaja antara lain:

1. Pengetahuan anatomi dan fisiologi manusia, serta perubahan-perubahannya yang terjadi pada masa puber. ${ }^{42}$

2. Pengetahuan tentang organ reproduksi, kehamilan, dan kelahiran. ${ }^{43}$

3. Cara merawat kebersihan dan kesehatan organ seks, dan penyakit-penyakit menular seksual. ${ }^{44}$

4. Pengaruh obat-obatan, narkotika, dan alkohol terhadap seksualitas. ${ }^{45}$

5. Alat-alat kontrasepsi dan pengaturan kesuburan, kehamilan, aborsi dan resikonya. ${ }^{46}$

6. Masalah-masalah fisiologi yang timbul akibat seks bebas.

\section{Dimensi Psikologis}

Di dalam perkembangan psikologinya, anak remaja sedang mencari jati dirinya yang sesungguhnya. ${ }^{47}$ Maka di dalam dimensi psikologis harus

\footnotetext{
${ }^{42}$ Herlianto, Aids dan Perilaku Seksual, (Bandung: Kalam Hidup, 1995), 53

${ }^{43}$ Ibid, 55.

${ }^{44}$ Ibid, 60.

${ }^{45}$ Ibid, 68.

${ }^{46}$ Ibid, 74
} 
menekankan bahwa prilaku seksual-genital hanyalah salah satu aspek saja dari sekian banyak cara pengungkapan seksualitas. Jika harus memasukinya, itu berkaitan dengan gambar tubuh, peran gender, peran sosial dan peran keluarga atau kenikmatan panca indra dalam ragam pengungkapan kasih sayang, cinta, dan keakraban. Unsur-unsur fundamental ini merupakan keseluruhan keberadaan keperibadian seseorang.

Prinsip yang ditanamkan dalam dimensi psikologis adalah bahwa seksualitas bukan merupakan hal yang terpenting dalam hidup. ${ }^{48}$ Anak-anak Allah harus berjuang untuk menempatkan seksualitas dalam perspektif yang benar yang sesuai dengan kebenaran firman Tuhan. Maka, di dalam dimensi psikologis ini, hal-hal yang penting untuk disampaikan kepada para remaja antara lain:

1. Kepribadian dan seksualitas.

2. Seksualitan yang berkaitan dengan identitas dan peran jenis masing-masing.

3. Perasaan terhadap seksualitas dan bagaimana menjalankan fungsinya sebagai mahluk sosial.

4. Faktor-faktor penyebab timbulnya seks di luar nikah.

5. Masalah-masalah psikologi yang ditimbulkan oleh seks di luar nikah.

\section{Dimensi Sosial}

Dari psikologi perkembangan sosial remaja, diketahui bahwa ada dorongan alamiah dalam diri remaja dari ketergantungan menuju kemandirian. Dalam usaha menuju kemandidirian tersebut, bila remaja tidak dibekali dengan nilai-nilai etika, maka di dalam pergaulannya akan melakukan hal-hal yang umum disebut "kenakalan remaja". Para remaja mendefinisikan kemandirian menjadi kebebasan. Kebebasan yang mereka pikirkan adalah kebebasan melakukan perbuatan-perbuatan yang berada di luar nilai-nilai kekristenan maupun norma-norma sosial masyarakatnya.

Tidak ada kebebasan di dalam dunia ini. Kebebasan yang berada di luar lehendak Allah adalah keterikatan di dalam perbuatan dosa. Stevri di dalam bukunya Theologi \& Misiologi Reformed menjelaskan bahwa, Kehendak bebas manusia, setelah kejatuhan manusia kedalam dosa, adalah kehendak yang dipengaruhi oleh dosa, sehingga kehendak manusia itu pun tidak benar-benar

${ }^{47}$ Sarlino Wirawan Sarwono, Psikologi Remaja, (Jakarta: Raja Grafindo Persada, 1989), 71-72

${ }^{48}$ Ibid. 
bebas, karena ia telah terikat dengan dosa. Namun, setelah Tuhan memperbaharui manusia, maka kehendaknya pun diperbaharui dan menjadi bebas tetapi terikat pada kebebasan Penciptanya. ${ }^{49}$

Di dalam perkembangan sosialnya, remaja sangat tertarik memahami apa artinya menjadi laki-laki dan wanita. Sosialisasi yang bersifat gender sering bersifat membatasi. Faktor-faktor sosial yang ada dalam masyarakat saat ini juga menciptakan pemisahan jiwa laki-laki dan jiwa wanita. Karena alasan-alasan ini, pemberian pengetahuan peran gender seyogianya merupakan bagian utama pendidikan seksual.

Konsep diri remaja sangat kuat dipengaruhi oleh faktor-faktor sosialisasi gender, pembelajaran keakraban, pendampingan, kelembutan terhadap orang lain dan nilai-nilai dalam konteks keluarga dan masyarakat. Pelajaran seksual remaja dalam dimensi sosial ini harus berisi penjelasan tentang perasaan, kasih sayang, dan keakraban dalam konteks pengharapan gender dan menjadi manusia seutuhnya, agar generasi mendatang dapat berinteraksi dengan orang lain dengan aman, akrab, dan mengasihi.

Dalam dimensi sosial ini, hal-hal yang penting untuk disampaikan kepada para remaja antara lain:

1. Seksualitas dan relasi antar manusia.

2. Pengaruh lingkungan dalam pembentukan pandangan mengenai seksualitas.

3. Perilaku seks merupakan pilihan.

4. Etika pergaulan remaja.

5. Berkencan, bercinta, dan perkawinan.

6. Seks dan hukum negara.

7. Masalah-masalah yang banyak dibicarakan, misalnya: perkosaan, masturbasi, homoseksualitas, disfungsi seksual, dan eksploitasi seksual.

8. Masalah-masalah sosial yang timbul akibat seks di luar nikah.

\section{Dimensi Spiritual}

Dimensi spiritual sangat penting dalam pendidikan seks kepada remaja. Dalam serangkaian eksperimen tentang perkembangan moral anak, Hartshorne dan May menemukan hal yang paling penting bahwa anak-anak yang menjadi anggota Sekolah Minggu menunjukkan kejujuran, kerja sama, ketekunan, dan 2006), 115.

${ }^{49}$ Stevri I. Lumintang, Theologi \& Misiologi Reformed, (Batu: Dep. Literatur PPII, 
menjauhi prilaku yang tidak diinginkan. ${ }^{50}$ Stevri, dalam kata pengantar bukunya "Re-Indonesianisasi Bangsa", menyatakan bahwa krisis suatu bangsa berakar pada krisis spiritualitas, berawal pada krisis mentalitas, berbuah pada krisis moralitas, bermuara pada krisis sosial, ekonomi, politik, hukum dan agama. ${ }^{51}$ Demikian juga perilaku seks bebas remaja yang merupakan krisis moralitas bangsa Indonesia ini, berakar dari krisis spiritualitas.

Dalam dimensi spiritual ini, hal-hal yang penting untuk disampaikan kepada para remaja antara lain: Maksud dan fungsi hukum Allah mengenai kesusilaan; Seks dan nilai-nilai moral Kristen; Seksualitas adalah pemberian Allah; Seks dan supremasi Kristus; Kebaikan seks dan kemuliaan Allah; Seks, kemesraan, dan kemuliaan Allah.

\section{Kesimpulan}

Seks tidak dianggap sebagai sesuatu yang tabu, atau najis melainkan sebagai sesuatu yang kudus dan patut dihormati sebagaimana diajarkan di dalam Alkitab. Oleh karena itu, pendidikan seks perlu diajarkan oleh orangtua kepada remaja, bahkan sejak masa kanak-kanak. Dalam masa remaja, seseorang akan mengalami perkembangan seksualitasnya. Oleh karena itu, remaja perlu mendapatkan informasi yang benar dan cukup tentang kehidupan seksualitasnya dari orangtuanya. Pendidikan seks pada remaja dengan tujuan untuk memperkuat pengembangan kepribadiannya. Sehingga melalui pendidikan seks diharapkan timbulnya sikap yang sehat dan bertanggung jawab terhadap seksualitasnya sesuai Alkitab dan norma-norma masyarakat setempat. Selain itu, untuk menghindarkan remaja dari perbuatan atau keterlibatan dalam perilaku seks yang salah seperti seks bebas, seks pranikah, kehamilan di luar nikah, penyakit kelamin, dan sebagainya.

\section{Daftar Pustaka}

Abineno, J.L. CH, Seksualitas dan Pendidikan Seksualitas Seksual, Jakarta: Bpk. Gunung Mulia, 2002.

Ahmadi, Abu, Psikologi sosial, Jakarta: Rineka Cipta, 2007.

Andrew, Michener, H. dkk, Sosial Psychology, Canada: Wadsworth, 2004.

Anne K. Hershberger, Michael A. Carrera Seksualitas Pemberian Allah, Jakarta: BPK Gunung Mulia, 2008.

\footnotetext{
${ }^{50}$ Paul D. Meier, dkk, 107.

${ }^{51}$ Stevri I. Lumintang, xi.
} 
Baron \& Donn Byrne, Robert A., Psikologi Sosial Vol 1, Jakarta: Erlangga, 2003.

Benson \& Mark H. Senter III, Warren S, Pedoman Lengkap Untuk Pelayanan Kaum Muda, Bandung: Kalam Hidup, 1999.

Brenna B. Jones, Stanton L, How And to Tell Your Kids About Seks, Surabaya: Momentum, 2004.

Clinebell, Howard, Tipe-tipe Dasar Pendampiungan dan Konseling Pastoral, Yokyakarta: Kanisius, 2002.

Davis, Ron Lee, Mentoring, The Strategy Of The Master, Nashville, Thomas Nelson Publishers, 1991.

Dyck, Anni. Tantangan dan Kebutuhan Remaja. Malang : YPPII, 1982

Emindyawati, Lilis, Peranan Guru Pendidikan Agama Kristen Terhadap Perilaku Siswa-Siswi, Fidei: Jurnal Teologi Sistematika dan Praktika, Vol. 2, No. 1, Juni 2019.

Guthrie, Donald, Theologi Perjanjian Baru, Vol 1, Jakarta: BPK Gunung Mulia, 2006.

Hurlock, Elizabeth B. Psikologi Perkembangan, Jakarta: Erlangga, 1980.

Hassan Shadily, John M. Echols, Kamus Inggris Indonesia, Jakarta: Gramedia, 2003.

Herlianto, Aids dan Perilaku Seksual, Bandung: Kalam Hidup, 1995.

Lumintang, Stevri, Pastoral Ecclesiology, Batu: Institut Injil Indonesia/I-3, 2008.

Lumintang, Stevri I, Re-Indonesianisasi Bangsa, Batu: Departemen Multi-Media YPPII, 2009.

Lumintang, Stevri I Theologi \& Misiologi Reformed, Batu: Dep. Literatur PPII, 2006.

Kristianto, Paulus Lilik, Prinsip \& Praktik Pendidikan Agama Kristen, Yokyakarta: ANDI, 2006.

Kamus Besar Bahasa Indonesia, Jakarta: Balai Pustaka, 2005.

M.D, Paul D. Meier dkk, Pengantar Psikologi dan Konseling Kristen Vol 1, Yokyakarta: ANDI, 2004.

Marx, Dorothy I, New Morality, Bandung: Kalam Hidup, 2005.

Mulyono, Y. Bambang. Mengatasi Kenakalan Remaja. Yogyakarta : Andi, 1996 Sahardjo, Hadi P, Konseling Krisis \& Terapi Singkat, Bandung: Pioner Jaya, 2008.

Sadarjoen, Sawitri Supardi Bunga Rampai Kasus Gangguan Psikoseksual, Bandung: Refika Aditama, 2005. 
Santrock, John W, Life-Span Development Vol 2, Jakarta: Erlangga, 2002.

Sarwono, Sarlito W, Psikologi Remaja, Jakarta: Raja Garafindo Persada, 1989.

Sarwono Sarlito W, Teori-Teori Psikologi Sosial, Jakarta: Raja Grafindo Persada, 2006.

Sears, David O, dkk, Psikologi Sosial, Jakarta: Erlangga, 1985

Surbakti, EB Kenakalan Orang Tua Penyebab Kenakalan Remaja, Jakarta: Elex Media Komputindo, 2008.

Stevanus, Kalis. Cekcok tapi Sudah Cocok. Yogyakarta: Andi, 2015

Stevanus, Kalis. Bible, Pray and Love. Yogyakarta: Andi, 2015

Stevanus, Kalis. Menjadi Orangtua Bijak Solusi Mendidik Dan Melindungi

Anak Dari Pengaruh Pergaulan Buruk. Yogyakarta: Yayasan Pustaka

Nusatama, 2016

Stevanus, Kalis. Mendidik Anak. Yogyakarta: Lumela, 2018

Stevanus, Kalis. "Tujuh Kebajikan Utama Untuk Membangun Karakter

Kristiani Anak“, BIA: Jurnal Teologi dan Pendidikan Kristen Kontekstual, Volume 1, No.1, 2018.

Suleman, Dadang. Psikologi Remaja. Bandung : Mandar Maju,1995

Yulia, Singgih D. Gunarsa, Psikologi Perkembangan Anak dan Remaja, Jakarta: BPK Gunung Mulia, 2006. 